УДК 621.396.933(075)

DOI:

Свген Кміта, кандидат педагогічних наук, Методист 1-ої категорії відділу тренажерної підготовки тренажерного иентру Навчально-сертифікаційного иентру Украероруху

\title{
КОГНІТИВНИЙ КОМПОНЕНТ ПРОФЕСІЙНОЇ (ІНШОМОВНОЇ) КОМУНІКАТИВНОЇ КОМПЕТЕНТНОСТІ ДИСПЕТЧЕРІВ УПРАВЛІННЯ ПОВІТРЯНИМ РУХОМ
}

Стаття присвячена безпеці польотів на міжнародних повітряних трасах. Розглядається професійна іншомовна комунікативна компетентність диспетчерів управління повітряним рухом, особливо ї̈ розвиток. У иүій роботі описується когнітивна система, саме поняття когнітивності, а також когнітивних компонент розвитку професійна іншомовна комунікативна компетентність диспетчерів управління повітряним рухом. Описані складові та елементи когнітивного компоненту стосовно авіаційної сфери, враховуючи саморегуляцію та відносно професійної іншомовної комунікативної компетентності диспетчерів управління повітряним рухом. При иьому зроблений наголос на те, шо особливості функиіонування когнітивного компоненту підпорядковуються вимогам документам Міжнародної організації циввільної авіації (ICAO) №9432 ma №9835.

Ключові слова: диспетчер управління повітряним рухом; професійна комунікативна компетентність; безпека польотів; когнітивна система; когнітивність; когнітивний компонент; знання; уміння; досвід творчоі діяльності; емоційне відношення.

Jim. 10.

Yevhen Kmita, Doctor of Sciences (Pedagogy), The 1st class Metodist of the Simulation Department Simulation Center of Training and Certification Center of UkSATSE

\section{THE COGNITIVE COMPONENT OF PROFESSIONAL (FOREIGN LANGUAGE) COMMUNICATIVE COMPETENCE OF AIR TRAFFIC CONTROLLERS}

The article is devoted to the flight safety on the international airlines. ICAO Assembly has signed Resolution A 32-16, relating to the role of language factor in aviation incidents and accidents. The professional (foreign language) communicative competence of air traffic controllers is defined, especially its development. This kind of professional competence is the union of professional and special foreign language communicative knowledge, skills and habits and the ability of their usage in the process of professional interaction during radiotelephony with aircraft crews on the international airlines in the conditions of any types of professional interaction and activity.

In this work the cognitive system, cognition term itself and the cognitive component of the professional (foreign language) communicative competence of air traffic controllers are described.

Cognitive system is a component of human consciousness and its general human cognition; it is a multilevel system, providing the realization of all central neural system cognitive functions. The main characteristics of cognitive system are: expressiveness, effectiveness, algorithmic, comprehensibility and adaptation.

Cognition is a term, defining the ability to mental perception and processing of external information In psychology this term is relating to mental personality processes, especially learning of so called 'mental states' (convictions, wishes and intentions) in terms of information processing. This term is especially often used in the context of "context knowledge" learning and in the spheres, which include knowledge, skills or learning.

The cognitive component elements and parts, taking into account self-regulation, were described, relating aviation sphere and professional (foreign language) communicative competence of air traffic controllers.

The cognitive component is a presence of the necessary minimum of foreign language knowledge, cognizance of the rational ways of communicative work with the operational information and information systems. Moreover, knowledge is understood as a general human experience, the reflection of reality in human consciousness. The radiotelephony culture cognitive component indicators are: the presence of required minimum of technological knowledge, creative activity means cognizance; the learners' educational activity.

Moreover, it was paid attention to the fact that the peculiarities of cognitive component functioning are dependent on the demands of ICAO Docs №9432 and №9835.

Keywords: an air traffic controller; professional communicative competence; flight safety; cognitive system; cognition; cognitive component; knowledge, skills; creative activity experience; emotional attitude.

П остановка проблеми. Погане знання розмовної мови є одним $з$ факторів, що сприяє виникненню авіаційних пригод.
Занепокоєння з приводу ролі мовного фактору в авіаційних пригодах призвело до прийняття резолюції А 32-16 Асамблеї ІСАО, яка нагально 
закликала Раду ICAO дати вказівки Аеронавігаційній комісії розглянути цю проблему в пріоритетному порядку і закінчити виконання поставленої задачі щодо посилення відповідних положень ICAO, які стосуються вимог щодо володіння мовою [2].

Проте катастрофи на міжнародних поваітряних трасах, які виникають внаслідок непорозуміння між пілотом і авіадиспетчером через обмежене володіння англійською мовою, все ще займають зачне місце.

Про це свідчить детальний аналіз більшості авіакатастроф, який показав, що їх причинами стали:

- несподівані переходи на рідну мову в процесі ведення радіообміну англійською мовою (характерні для диспетчерів як західноєвропейських, так і східнослов'янських країн, для яких англійська мова не є рідною);

- перенесення диспетчерами знань інших мов, як рідної, так іноземної, на процес ведення радіообміну англійською мовою;

- невиконання вимоги ICAO Doc. AN9432: “...Учитывая, что у человека-оператора, принимающего сообщения, английский язык возможно не является родным языком. Поэтому говорите ясно и, как правило, используйте стандартные фразы и ситуации...” [8].

Навіть аналіз виписок із магнітофонних записів радіозв”язку “пілот-диспетчер” аеропорту м.Миколаєва в стандартних умовах польоту показали вплив розмовного англійської й російської мов на процес ведення диспетчером радіообміну англійською мовою:

- наявність зайвих прийменників, артиклів і слів;

- використання слів російської мови замість англійського;

- запозичення лінгвістичних конструкцій, що є потенційними причинами виникнення тих або інших нестандартних ситуацій.

Складність використання для прийому та передавання інформації мови, що не є для авіадиспетчера рідною (наявність низької іншомовної компетенції) і якою він володіє не повною мірою, обумовлена не тільки структурномовними нормами конкретних мов. Істотний вплив на безпеку польотів робить національнокультурна специфіка мовного спілкування, “бар'єр”, створюваний мовними стереотипами, звичками: скорочення можуть бути сприйняті 3 опорою або на звуковий код, або на графіку рідної мови (особливо при неповноті інформації, що надходить, в умовах дефіциту часу); виникає інтермовна інтерференція, подолання якої збільшує час декодування повідомлення тощо.
Стає зрозумілим брак професійної іншомовної комунікативної компетентності авіадиспетчера через деформацію когнітивної функції в процесі ведення радіообміну англійською мовою.

Відзначимо, що вітчизняними науковцями визначено основні характеристики фахівця, якого можна назвати компетентним у професійнокомунікативному плані, а саме такі: 1) здатність виконувати поставлені завдання, дотримуючись при цьому найбільш ефективних шляхів їх вирішення; 2) прихильність до обраної професії, сформованість мотивації щодо професійної праці; 3 ) результативність професійної роботи; 4 ) засвоєння норм і еталонів професійної діяльності; 5) забезпечення постійного професійноособистісного самовдосконалення; 6) наявність необхідного рівня знань і умінь для результативної роботи, розвиненість умінь аналізувати та прогнозувати свій подальший професійний розвиток; 7) готовність до постійного накопичення професійного досвіду, його збагачення за допомогою участі в різних видів творчої фахової діяльності; 8) уміння об'єктивно оцінювати рівень власної професійної підготовки.

Зрозуміло, що професійна іншомовна комунікативна компетентність є невід'ємною частиною професійної діяльності індивіда, бо саме вона відображає особистісні якості та властивості фахівця, за допомогою яких він самостійно й ефективно реалізовує завдання професійної діяльності, в тому числі ті, що пов'язані з діями інших людей [7].

Професійна (іншомовна) комунікативна компетентність диспетчерів управління повітряним рухом (далі - УПР) - це професійні та фахові іншомовні комунікативні знання, навички, вміння та здатність їх адекватного використання для здійснення службової взаємодії в процесі ведення радіообміну з екіпажами повітряного судна, які здійснюють польоти на міжнародних повітряних трасах, в тих або інших умовах професійної взаємодії та діяльності.

Мета статті. Розкрити ключові елементи когнітивного компоненту професійної (іншомовної) комунікативної компетентності диспетчерів УПР; визначити особливості їх функціонування у процесі розвитку професійної іншомовної компетентності диспетчерів управління повітряним рухом.

Аналіз останніх досліджень та публікацій. Поняття та зміст іншомовної комунікативної компетентності вивчалося та досліджувалось вченими з усього світу (Л. Біркун, Л. Брахман, О. Волобуєва, Г. Китайгородська, С. Козак, Е. Пассов, С. Савіньон, М. Свейн, Д. Хаймс, Д. Шейлз та 


\section{КОГНТТИВНИЙКОМПОНЕНТПРОФЕСЙНОЇ(ІНШОМОВНӦ̈) КОМУНІКАТИВНОӤ КОМПЕТЕНТНОСТІ ДИСПЕТЧЕРІВ УПРАВЛІННЯ ПОВІТРЯНИМ РУХОМ}

ін.). Дослідження показали, що на даний час відсутні універсальне визначення поняття іншомовної комунікативної компетентності та його компонентів [1].

Особливості професійного іншомовного спілкування авіаційних операторів дискутувались упрацях Б. Алякринського, В. Колосова, А. Пчелінова, В. Цвєткова. Елементи авіаційного дискурсу досліджували О. Акімова, Д. Бродбент, Т. Мальковська, Х. Савін, В. Спіт, Ф. Фрік та ін. Більшість авторів єдині в тому, що вірне іншомовне спілкування авіадиспетчерів та пілотів $є$ одним з важливіших факторів авіаційної безпеки [1].

Психологічні особливості професійномовленнєвої діяльності пілотів і авіадиспетчерів були предметом уваги Н. Завалової, Г. Карапетяна, В. Козлова, Р. Макарова, Н. Михайлика, В. Пономаренка, В. Ягупова та ін. Питання мовної підготовки авіаційних фахівців були об'єктом досліджень вітчизняних вчених (В. Півень, Г. Пащенко, Г. Пухальська, Т. Тарнавська), що визначили, які саме компоненти повинні входити до іншомовної підготовки авіадиспетчерів та пілотів та роблять наголос на комунікативності самого процесу радіообміну [1].

Когнітивність та ії елементи досліджувалися вченими Е. Рош, Дж. Лакофф, Дж. Тейлор (теорії прототипів і природна категоризація), Ф. Ленекер (теорія виділення), Л. Талмі, Ч. Філлмор (концентрація або фокусування уваги). Більшість авторів єдині в важливості наявності досвіду взаємодії людей 3 довкіллям. 3 точки зору когнітивної лінгвістики у теорії концепту розглядаються декілька основних підходів до його розуміння: лінгвокультурний (А. Вежбицька, В.І. Карасик); психолінгвістичний (В. Красних, Р. Фрумкіна); семантичний (М. Алефіренко, Н. Арутюнова); етнічний (О.В. Городецька, О.С. Кубрякова, Д. Лихачов); сочіо-психокультурний (Ю. Апресян).

Виклад основного матеріалу. Людина здійснює пізнавальну (когнітивну) діяльність, бо вона активно ставить перед собою мету, намагається іiі досягти. Пізнання не є пасивним процесом, воно завжди поєднане з перетворенням пізнаного. В пізнанні розрізняють два ступені так званого чуттєвого відображення i відображення абстрактно-теоретичного [5].

Інтелектуальну діяльність людини-оператора пов'язують передусім з відображувальною і регулятивною діяльністю, що полягає у здатності ефективно розв'язувати задачі, навчатися використовувати набутий досвід для вирішення нових проблем, краще пристосовуватися до нової ситуації (що дуже важливо при веденні радіообміну англійською мовою на міжнародних повітряних трасах) [5].

Велике значення в інтелектуальних здібностях авіадиспетчера має співвідношення теоретичного і практичного, логічного й образного компонентів. Інтелектуальні операції та досвід здебільшого пов'язані з реальними предметами і діями з ними чи з їхніми символічними означеннями.

Інтелектуально-творча ж, когнітивна сфера особистості забезпечує динамічне відображення дійсності та ії перетворення, формування досвіду, побудову моделі світу, регуляцію діяльності. У цій сфері специфічно взаємодіють психічні процеси, забезпечуючи єдиний потік цілісної свідомої відображувальної та перетворювальної продуктивної діяльності [5].

3 точки зору професійної підготовки авіаційних фахівців когнітивність вживається в контексті вивчення так званого “контекстного знання" (тобто абстрактизации і конкретизації), а також у тих областях, де розглядаються такі поняття, як знання, уміння або навички [6].

Загалом теорія когнитивности часто всього лише описує поведінку людини-оператора в термінах інформаційного потоку або функціонування (є невід'ємними складовими процесу ведення радіообміну “диспетчер управління повітряним рухом - екіпаж повітряного судна") [6].

До того ж базою любого спілкування диспетчера управління повітряним рухом $є$ його когнітивна система.

Під когнітивною системою розуміють систему пізнання, що склалася в свідомості людини в результаті становлення їі характеру, виховання, навчання, спостереження і роздумів про навколишній світ. На основі цієї системи людина ставить собі цілі і приймає рішення про те, як треба діяти в тій чи іншій ситуації, намагаючись уникнути когнітивного дисонансу. В основі когнітивної системи лежить взаємодія сприйняття, свідомості, пам'яті та мови; носієм такої системи $\epsilon$ мозок людини [10].

Останні складаються 3 певних когнітивних структур. 3 цими структурами зазвичай пов'язують певні когнітивні процеси, які відносяться до наборів операцій (функцій), що дозволяють отримувати, аналізувати, змінювати і переробляти інформацію (наприклад функції осмислення, формування понять, забування) [9].

Визначальними ознаками когнітивної системи $\epsilon$ : виразність (що вербалізується засобами системи мови); ефективність (націленість на швидке і ефективне вирішення практичних завдань); алгоритмічність (будується на 


\section{КОГНТТИВНИЙ КОМПОНЕНТ ПРОФЕСІЙНОЇ (ІНШОМОВНОЇ) КОМУНІКАТИВНОӦ КОМПЕТЕНТНОСТІ ДИСПЕТЧЕРІВ УПРАВЛІННЯ ПОВІТРЯНИМ РУХОМ}

алгоритмах); засвоюваність (система засвоюється людиною в результаті навчання); адаптованість [3].

Різні когнітивні системи об'єднуються в єдину інфраструктуру, іменовану архітектурою когніції [3].

В когнітивній лінгвістиці мовна здатність (англ. language faculty) людини представляється як окрема когнітивна система. Розрізняються дві підкомпоненти мови - зберігання інформації (англ. competence) і реалізації (англ. performance systems), які здійснюють доступ до інформації при артикуляції, сприйнятті і обміні відомостями про навколишній світ [3].

Над когнітивною системою знаходиться когнітивний компонент, який виступає як наявність необхідного мінімуму іншомовних знань; знання раціональних способів комунікативної діяльності 3 операційною інформацією й інформаційними системами тощо диспетчера УПР та готовність до їх розвитку. Показники, що визначають когнітивний компонент радіомовної культури: наявність необхідного мінімуму технологічних знань; знання засобів творчої діяльності та правил ведення зв'язку; пізнавальна активність слухачів [4].

Європейське співтовариство трактує когнітивний компонент як "готовність до постійного підвищення освітнього рівня, потреба в актуалізації та реалізації свого особистісного потениіалу, здатність самостійно здобувати нові знання та вміння, здатність до саморозвитку” [4].

Інтегруючи підходи до розкриття змісту поняття “когнітивний компонент", можна сформулювати таки висновки, що всі автори висувають на перший план підвищення освітнього рівня суб'єкта, акцентуючи увагу на знанні технологій навчальної діяльності, на самоврядуванні навчальної діяльності, на володінні пізнавальними компетенціями.

Когнітивний компонент професійної іншомовної комунікативної компетентності диспетчера УПР загалом містить наступні складові: мотиваційна; когнітивно-операційна; діяльнісна; оцінна [4].

Беручи до уваги, що компетентність формується та розвивається в діяльності, необхідно акцентувати, що важливим елементом когнітивного компоненту є саморегуляція навчально-пізнавальної або професійної діяльності (визначення мети діяльності, аналіз та виявлення значущих умов, вибір кращого способу i послідовності дій, оцінка результатів та їх корекція в разі необхідності - підлеглих усвідомлюваного людиною процесу визначення мети й цілездійснення) [4].
3 точки зору розвитку професійної іншомовної комунікативної компетентності авіадиспетчерів когнітивний компонент найкраще описаний у наступних елементах:

- відображення чотирьох основних елементів змісту навчання (знання, уміння, досвід творчої діяльності і емоційне відношення);

Слухач повинен

Знати:

- основні граматичні структури та моделі речень;

- авіаційну термінологію;

- лексичний матеріал в обсязі якнайменш відповідно до 4 рівня за шкалою ICAO;

- особливості ведення радіотелефонного зв'язку під час стандартних ситуацій професійної діяльності;

- особливості ведення радіотелефонного зв'язку під час виникнення нестандартних / аварійних ситуацій у польоті.

Вміти:

- використовувати основні граматичні структури та моделі речень свідомо та доцільно, до того ж доцільно використовувати словниковий запас;

- доводити інформацію до співрозмовника/ пілота; видавати рекомендації, вказівки, приймати та підтверджувати інформацію, здійснювати запити та відповідати на них;

- успішно і відносно легко впоратися із лінгвістичними труднощами, які виникають через ускладнений, або неочікуваний хід подій, що має місце в межах контексту звичайної робочої ситуації, або комунікативного завдання;

- розв'язувати непорозуміння через перевірку, підтвердження або уточнення;

- надавати усні доповіді;

- підтримувати мовний зв'язок за умов відсутності візуального контакту (no visitai contact) та при безпосередньому контакті зі співрозмовником/пілотом (face to face);

- висловлювати свої думки недвозначно та лаконічно;

- слухати й чути;

- сприймати та розуміти мовну інформацію від співрозмовника/пілота;

- переключатися та підтримувати відповідний темп мовлення при переході зі стандартної фразеології ICAO на загальну англійську мову або 3 англійської на російську;

- застосовувати адекватно мовленнєві навички та вміння в разі виникнення аварійних ситуацій або непередбачуваних обставин у польоті;

- використовувати парафрази в нестандартних ситуаціях. 


\section{КОГНІТИВНИЙКОМПОНЕНТПРОФЕСІЙНОЇ(ІНШОМОВНОЇ) КОМУНІКАТИВНОЇ КОМПЕТЕНТНОСТІ ДИСПЕТЧЕРІВ УПРАВЛІННЯ ПОВІТРЯНИМ РУХОМ}

\footnotetext{
Мати навички творчої діяльності, а саме:

- мобілізовувати свої іншомовні ресурси або підбирати їх оптимальне сполучення для виконання потрібностей комунікації в тому або іншому контексті/ситуації повітряного руху та виконання задач найбільш оптимальним способом у процесі ведення радіообміну англійською мовою.

Мати емоційне відношення:

- готовності та здатності ведення радіозв'язку англійською мовою як в стандартних, так і в нестандартних / аварійних ситуацій у польоті.

Очікуванні результати навчання (відповідно до ICAO Doc 9835)
}

При веденні радіозв'язку англійською мовою:

а) прояв іншомовних комунікативних навиків, заснованих на компетентностях, на відміну від простого відтворення або демонстрації заучених знань;

b) демонстрація складного навичка*, який $€$ результатом інтеграції в реальному часі ряду субнавиків, що складають професійну іншомовну комунікативну компетентність. У число цих субнавиків ( серед інших ) входять: активація запасу слів і виражень із лексикону мови радіообміну; застосування засвоєних граматичних правил; використання засвоєних синтаксичних правил; сприйняття й артикуляція звуків і інтонації, що становлять осмислений звуковий потік; пристосування до численних мовних, соціальних, культурних і професійних ситуацій (стандартних, незвичайних, аварійних) та норм у контексті інтерактивної комунікації.

с) чітке, вірне та ясне використання загальної англійської мови, авіаційної англійської мови та фразеології радіообміну у процесі ведення радіозв'язку “диспетчер УПР - екіпаж ПС”.

(*Усі компетентності, необхідні для володіння мовою, являють собою “конструкти” психічних і фізичних здатностей, які не піддаються прямому спостереженню. Судити про наявність даних здатностей у того або іншого індивідуума можна тільки на основі спостережень за його язиковою поведінкою. Однак у процесі вживання мови на язикову компетентність можуть впливати такі фактори, як рівень уваги, настрій, стрес, робочий обсяг вербальної пам'яті й здатність до обробки вербальної інформації. Ці фактори, у свою чергу, впливають на рівень показників швидкості мови, розуміння мови на слух і здатності до мовної взаємодії.

Таким чином, демонстрація навичок не тотожна компетентності, але поки що служить єдиним способом судити про наявність язикової компетентності й оцінити ії рівень.)
Також враховується структура професійної комунікативної компетентності (відповідно до ICAO Doc 9835), яка містить такі складові:

- іншомовний компонент (знання та навички володіння англійською мовою відносно до рідної);

- лінгвістичний компонент:

- лексико-семантичний субнавик;

- граматичний субнавик (правила синтаксису та морфології);

- фонологічний (звуки, фразовий наголос, ритм, інтонація тощо).

- соціолінгвістичний компонент:

- знання соціального (в тому числі професійного) контексту, в якому використовується мова.

- прагматичний компонент (використання мовних засобів у певних функціональних цілях відповідно до ситуації та контексту:

- стратегічна компетентність (вміння користувачем мови мобілізувати свої ресурси або підібрати їх оптимальне сполучення для виконання потрібностей комунікації в тому або іншому контексті та виконання задачі найбільш оптимальним способом);

- дискурсивна компетентність (здатність поєднувати речення у зв'язний текст);

- функціональна компетентність (знання правил, що визначають традиційну або контекстуальну інтерпретацію мовних структур (“функцій”) та засобів загальноприйнятного використання цих функцій для створення структур діалогічної взаємодії та здатність ними користуватися);

- оцінка результатів використання мови в реальних ситуаціях, наприклад, в плані впливу на безпеку або ефективність діяльності.

До неї відносяться когнітивно-орієнтовані технології (діалогічні, проблемні, задачні, інформаційно-комунікативні), або технології повного засвоєння знань.

Висновки та перспективи подальших досліджень. Враховуючи усе вищезазначене можна зробити наступні висновки: когнітивний компонент розвитку професійної іншомовної комунікативної компетентності диспетчерів УПР $є$ дуже складним утворенням, яке функціонує відповідно до особливостей мови ведення радіозв'язку, професійної авіаційної діяльності та особистості людини - оператора. Напрямком подальшого дослідження може бути експеримент стосовно вивчення функціонування складових когнітивного компоненту диспетчерів УПР шляхом використання високоточних диспетчерських тренажерів. 


\section{ЛІТЕРАТУРА}

1. Богуш А.М., Ковтун О. В. Теоретичні і практичні аспекти формування мовної компетентності майбутніх пілотів і авіадиспетчерів. Вісник НТУУ “КПІ”. Філологія. Педагогіка: збірник наукових праць. 2014. Вип. 4. C. $66-74$.

2. Васюкович О.М. Педагогічні умови, сучасна освітня технологія, майбутні авіадиспетчери, професійна компетентність. 2015. ULR: http://er.nau.edu.ua:8080/handle/NAU/18156

3. Демьянков В.3., Демьянков В. 3., Панкрац Ю. Г., Лузина Л. Г. Когнитивная система. Краткий словарь когнитивных терминов. Москва, 1996. C.74-76.

4. Зміст когнітивної компетентності суб'єктів освітнього процесу. URL: https://s50d0214c 648ca362.jimcontent.com/download/version/ 1386075089/module/8779661021/name/1.1.doc.

5. Когнітивна сфера особистості. URL: https:// pidruchniki.com/1157071837214/psihologiya/ kognitivna_sfera_osobistosti

6. Когнітивність. URL: http://psychologis. com.ua/kognitivnost.htm

7. Пляка Л.В. Структура професійної комунікативної компетентності майбутніх провізоров. журнал Академії педагогічних наук України. Київ, 1993. С.74-78.

8. Руководство по внедрению требований ИКАО к владению язиком. Doc 9835 AN/453 - 2е изд. 2010. 180с.

9. Солсо Р. Когнитивная психология. 6-е изд. - Санкт-Петербург, 2006. 589 с.

10. Хомякова Е.Г. Информационная-когнитивная система и её актуализация в языке. Коммуникация и образование. Сборник статей. Под ред. С. И. Дудника. СПб. : Санкт-Петербургское философское общество, 2004. С. 180-197.

\section{REFERENCES}

1. Bohush, A.M. (2014). Teoretychni i praktychni aspekty formuvannia movnoi kompetentnosti maibutnikh pilotiv $i$ aviadyspetcheriv [Theoretical and practical aspects of future pilots and controllers language competence forming]. Bulletin of NTUU "KPI". Philology. Pedagogy: a collection of scientific works. Kyiv, vol. 4, pp. 66-74. [in Ukrainian].

2. Vasiukovych, O.M. (2015). Pedahohichni umovy, suchasna osvitnia tekhnolohiia, maibutni aviadyspetchery, profesiina kompetentnist. [Pedagogical conditions, modern educational technology, future controllers, professional competence]. Available at: http://er.nau.edu.ua:8080/ handle/NAU/18156 [in Ukrainian].

3. Demyankov, V. Z. (1996). Kognitivnaya sistema. Kratkiy slovar kognitivnykh terminov. [Cognitive system. Cognitive terms brief dictionary]. Moscow, pp.74-76. [in Russian].

4. Zmist kohnityvnoi kompetentnosti subiektiv osvitnoho protsesu [The plot of educational process congnitive competence]. Available at: https:// s50d0214c648ca362.jimcontent.com/download/ version/1386075089/module/8779661021/name/ 1.1.doc. [in Ukrainian].

5. Kohnityvna sfera osobystosti [The personal cognitive sphere]. Available at: https:// pidruchniki.com/1157071837214/psihologiya/ kognitivna_sfera osobistosti [in Ukrainian].

6. Kohnityvnist [Cognition]. Available at: http:// psychologis.com.ua/kognitivnost.htm [in Ukrainian].

7. Pliaka, L.V. (1993). Struktura profesiinoi komunikatyvnoi kompetentnosti maibutnikh provizorov [The structure of future provisors professional communicative competence]. Journal of the Academy of Pedagogical Sciences of Ukraine. Kyiv, pp.74-78. [in Ukrainian].

8. Rukovodstvo po vnedreniyu trebovaniy IKAO $k$ vladeniyu yazykom (2010). [ICAO Guidelines on Language Competency]. Doc 9835 AN/ 453, vol 2, 180p. [in Russian].

9. Solso, R. (2006). Kognitivnaya psikhologiya [Cognitive psychology]. Sankt-Peterburg, vol. 6, 589p. [in Russian].

10. Khomyakova, Ye. G. (2004). Informatsionnayakognitivnaya sistema i ee aktualizatsiya $\mathrm{v}$ yazyke. [Information and cognition system and its language actualisation]. Communication and education. Digest of articles. Sankt-Peterburg, pp. 180-197. [in Russian].

Стаття надійшла до редакції 09.09.2019

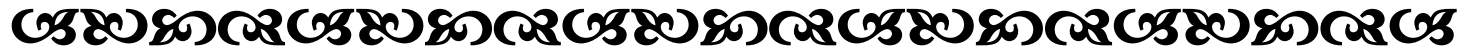

"Життя вимірюється не қількістю наших вдохів, а қількістю моментів, від яқих перехоплює дихання".

\section{G5808nc2058080}

